\title{
METHODS EMPLOYED IN RESEARCH ON THE SPATIAL STRUCTURE OF AGRICULTURE
}

\author{
AnNa KoŁodZIEJCZAK \\ Institute of Socio-Economic Geography and Spatial Management, Adam Mickiewicz University, Poznań, \\ Poland
}

Manuscript received: September 30, 2012

Revised version: September 5, 2013

KoŁodZIEJCZAK A., 2013. Methods employed in research on the spatial structure of agriculture. Quaestiones Geographicae 32(4), Bogucki Wydawnictwo Naukowe, Poznań, pp. 33-38, 1 table. DOI 10.2478/quageo-2013-0031, ISSN 0137-477X.

ABSTRACT: The research conducted in the field of agricultural geography concerns both, the conditions and factors controlling the spatial structure of rural areas. It includes several lines of study, like an assessment of the natural environment for agricultural purposes, designing land-use maps, examining agricultural suburban zones, model approaches to agriculture, the spatial structure of agriculture, methods of the typology and regionalisation of agriculture, or multi-functionality of agriculture. They make use of a great variety of methods. This article presents methods employed in research on the spatial structure of agriculture. It defines the notion of a spatial structure, the consequences that follow from it, and methodological assumptions. The methods discussed embrace statistical methods of studying the spatial structure of agriculture, those used to determine elements predominating in this structure and to describe its heterogeneity, as well as mathematical and spatial-econometric models.

KEY wORDS: agricultural geography, spatial structure of agriculture, research methods

Anna Kołodziejczak, Institute of Socio-Economic Geography and Spatial Management, Adam Mickiewicz University, ul. Dzięgielowa 27, 61-680 Poznań, Poland; e-mail: aniaka@amu.edu.pl

\section{Introduction}

Agricultural geography is concerned with social, economic and natural processes diversifying the rural economy in spatial terms; it analyses and explains the reasons of this diversification. Its subject matter is agriculture treated as a complex or a system in which all components are more or less interconnected and interdependent. Studies in this field deal with the conditions and factors that crucially affect its spatial structure.

According to Falkowski and Kostrowicki (2005), the chief methodological streams in agricultural geography focus on the following:

- assessment of the natural environment for farming purposes,
- preparation of land-use maps,

- studies of agricultural suburban zones,

- models of agriculture,

- studies of the spatial structure of agriculture,

- methods in the typology and regionalisation of agriculture, and

- studies of the multi-functionality of agriculture.

There is a great variety of research methods used in those fields. The aim of this article is to present methods employed in research on the spatial structure of agriculture. 


\section{The notion of the spatial structure of agriculture}

The spatial structure is a vital issue in examining the reality that surrounds us. The conceptual assumptions of a structure and basic types of its change are explained by Chojnicki (1999), who states that "the notion of a structure is highly ambiguous. Of basic importance in the various ways of understanding a structure is treating it as an object of relations holding among elements of the given whole, i.e. the given system". He then goes on to present the nature of spatial relations: "they are separating and ordering in nature rather than binding, but they are a condition of interaction" (Chojnicki 1999: 266).

The spatial structure of agriculture is understood as a set of interdependent features, phenomena and processes connected with farming that hold in a given area. Its characterisation embraces a set of internal features, like the agrarian structure, intensity of organisation of agriculture, agricultural land-use pattern, agricultural production, productivity and commercialisation of agriculture, and its typology (Falkowski, Kostrowicki 2005).

The spatial structure of agriculture is moulded by two basic processes: integration and differentiation. Integration processes manifest themselves in the globalisation of agriculture at the geographical, organisational and institutional levels. Those of spatial differentiation show in a non-homogeneous distribution of material and social resources as well as in the intensity of agriculture. Studies of the spatial structure of agriculture are part of research on rural areas.

Agricultural geographic research deals with the transformation of the spatial structure of farming and its stability as well as barriers created by both, changes in its elements and the very system of spatial relations and interactions occurring among them. Interesting from the geographical perspective are changes in the links binding the spatial structure and in their functions, because they bring about a modification in the principles of development of the structure and in spatial organisation (Chojnicki 1999). Dynamic spatial structuralism shows in the following directions of change: 1. a spread of the elements of the structure,

2. growth in spatial terms, and
3. changes in spatial links.

In the light of the above, Runge (2006) claims that an in-depth study of spatial structures of agriculture should seek to answer the following questions:

1. Which elements are significant from the point of view of the entire structure?

2. How do elements of the given structure change in space and time?

3. How do relations among elements of the structure change? and

4. What is the nature of long-term structural changes?

The way in which research results are presented makes it possible to divide the methods employed into aspatial and spatial. In the former, the result is usually a numerical index, an equation, etc.; in the latter, a territorial presentation in the form of a map of some type.

\section{Research methods}

The traditional methods of studying the spatial structure of agriculture can be divided into descriptive and statistical. In describing spatial distributions of selected properties of the structure, use is made of basic statistical measures: of location (arithmetic mean, median), variability (standard deviation, coefficient of variation), and structure (structure index, index of structure dissimilarity).

Important in research on the spatial structure of agriculture are interrelations holding among its elements. Answers are sought to such questions as whether there is a correlation between the analysed phenomena and if so, what is its magnitude and character as well as the level of significance. Correlation analysis makes it possible to identify single cases of interrelation; if applied in a multivariate analysis, a correlation matrix is employed to choose classification variables.

When studying the spatial structure of e.g. potato crops, use is made of autocorrelation in space and autocorrelation in time. Spatial autocorrelation is a correlation among the observed values of one variable at various points in space, this being a departure from the assumption of independent observation in classic statistics. An analogous variant of conventional correlation is autocorrelation in time, where the value of the observed 
variable may depend on earlier observations. Unlike autocorrelation in time, which is unidirectional, spatial autocorrelation is multi-directional (Kołodziejczak 2002).

Among the statistical methods useful in research on the spatial structure of agriculture, worth noting are canonical analysis and principal components analysis. Canonical analysis is a generalisation of multiple regression and involves a search for connections between two subsets of variables, one containing independent variables and the other, dependent variables. It allows one to determine relationships holding between two multi-dimensional sets of variables by helping to reduce the number of input variables while preserving the information about the relations between the sets (Głębocki 1979).

Principal components analysis is one of the methods of factor analysis which makes it possible to identify structures and reduce many variables to one or more factors. The theoretical foundations of principal components analysis can be found, e.g., in Morrison (1967), Chojnicki and Czyż (1978), or Parysek and Ratajczak (1978, 2002). The similarity between canonical analysis and the principal components method is that in both methods there is a reduction in multi-dimensional space and the variables obtained are not empirically verifiable; canonical variables, like principal components, are not physically observable. The difference consists in the fact that principal components analysis examines variability inside one set of variables, hence it is referred to as an internal method. In turn, canonical analysis concerns dependences between a basic set and a so-called external set, hence it is sometimes termed an external method.

In agricultural geography use is also made of a classification of elements of a structure with the help of cluster analysis. This is a method of grouping elements into relatively homogeneous classes on the basis of similarity between elements as expressed by means of a similarity function. The most popular grouping techniques are $k$-means and fuzzy clustering (Parysek 1980, Nowak 2004).

An important achievement of agricultural geography has been the popularisation of methods for determining elements that dominate in a structure. In a synthetic research on agricultural land use, arable land use, livestock husbandry or the size of agricultural holdings, all methods seek to establish mutual proportions of the particular elements and to identify elements dominating in their structure. Those methods perform two tasks. On the one hand, the patterns found for a large number of territorial units provide detailed information about the structure of the elements, and on the other, they are generalised enough to enable a synthesis and a cartographic presentation. One of such methods has been worked out by Weaver (1956). The essence of Weaver's procedure is a comparison of $n$-element combinations of models of an empirical structure against so-called theoretical models in which one seeks, using a variance formula, a model that best fits the structure observed while indicating elements that dominate in it:

$$
s^{2}=\frac{\sum_{i=1}^{n} d^{2}}{n}
$$

where:

$d$ - difference between the mean from the hypothetic distribution and the actual share of a variable in the structure, and

$n$ - number of elements in the given structure.

This method fails if individual elements contribute equally to the structure.

To determine directions, or elements dominating in the given structure, use is made of the method of successive quotients designed in the Institute of Geography of the Polish Academy of Sciences. It takes the form of the formula:

$$
\Sigma \mathrm{W}=\max
$$

where:

$$
\mathrm{W}=\mathrm{d} / \mathrm{i}
$$

$d$ - individual categories of elements in the structure examined,

$i$ - number of quotients $(1,2, \ldots n)$.

The direction is determined by a selected number of the highest quotients in the individual categories of elements. The level of detail in the directions being determined depends on the number of quotients adopted: the higher it is, the more detailed the description (Bański 2007). To determine directions in the use of arable land, livestock husbandry or farm-size tendencies, six successive quotients are usually employed, and 
the optimum number for directions in the use of agricultural land is ten. Advantages of this method are a high degree of objectivity and simplicity of the calculating procedure.

In synthetic studies of the spatial structure of agriculture also other methods are employed to determine differences in it. Among them is Cramer's diversification index, which allows us to identify differences in the spatial structure of crops or livestock husbandry. It can also serve to determine the level of concentration of a phenomenon under study. This index is equal to the smallest number of elements in the given structure embracing a minimum of $75 \%$ of the total number of elements. Its calculation first requires an ordering of territorial units by a decreasing share in the structure examined, and then for each year studied calculations are made of the number of territorial units embracing a minimum of $75 \%$ of the total number of element examined (Cramer, Clarence 1994):

$$
W_{n}=W_{s}-\frac{(a+b+\ldots .+m)-75}{m}
$$

where:

$W_{n}$ - diversification index,

$W_{s}$ - crude diversification index,

$a, b, \ldots . . ., m$ - share of elements in the successive objects that makes up the crude diversification index.

Differences in a spatial structure can be studied using a measure of inequality based on the Gini coefficient. It is defined as double the area between the Lorenz curve and the 'full diversification' line, and is a measure of so-called pure diversification, which corresponds to the term 'uniformity of distribution'. The Gini coefficient is calculated with the help of the following formula:

$$
G(y)=\frac{\sum_{i=1}^{n}(2 i-n-1) y_{i}}{n^{2} \bar{y}}
$$

where:

$y_{i}$ - value of the $i$-th observation,

$\bar{y}$ - mean value of all observations, and

$n$ - number of units.

The $y_{i}$ values are arranged in ascending order, and $i$ is the number of a unit in an increasing sequence. The Gini coefficient is a number in the interval $[0 ; 1]$. If $G=0$, there is full uniformity of the distribution, with $G=1$, there is no such uniformity (Davies 1980, Kołodziejczak 2010).
A method of examining spatial differences in the individual elements of a structure is also the use of entropy measures. An important problem in determining differences in the various elements of the structure is the choice of variables similar in rank to serve as criteria in the assessment of diversification.

Useful in research on the spatial structure of agriculture is the method devised by Kopeć (1984) and intended to determine the intensity of organisation of agriculture. Its level is determined on the basis of the crop structure and livestock capita per unit area as well as indicators of labour intensity that characterise each plant and animal species, using the formula:

$$
I=I_{R}+I_{Z}=\Sigma\left(p^{*} s\right)+\Sigma\left(q^{*} t\right)
$$

where:

$I$ - coefficient of the intensity of organisation of agriculture,

$I_{R}$ - coefficient of the intensity of crop production organisation,

$I_{Z}$ - coefficient of the intensity of animal production organisation,

$p$ - proportion of crops, meadows, pastures and orchards in total agricultural land,

$s$ - indicator of labour intensity for individual groups of crops,

$q$ - livestock units per 100 ha agricultural land,

$t$ - indicator of labour intensity for individual livestock species.

\begin{tabular}{|c|c|c|}
\hline \multirow[b]{2}{*}{$\begin{array}{c}\text { Degree } \\
\text { of intensity }\end{array}$} & \multicolumn{2}{|c|}{ Intensity coefficient } \\
\hline & $\begin{array}{l}\text { of organisation } \\
\text { of agriculture }\end{array}$ & $\begin{array}{l}\text { of organisation of } \\
\text { crop and animal } \\
\text { production }\end{array}$ \\
\hline extensive & under 200 & under 100 \\
\hline non-intensive & $200-250$ & $100-125$ \\
\hline medium intensive & $250-300$ & $125-150$ \\
\hline highly intensive & $300-350$ & $150-175$ \\
\hline very intensive & over 350 & over 175 \\
\hline
\end{tabular}

To determine the intensity of organisation of agriculture, a 5-degree scale is employed:

Source: Kopeć (1984).

The presented research methods are classic ones. They are well known, and their application range has been growing with the possibilities offered by computer software. 
The great advances in information science have made it possible to work out new methods of research on the spatial structure of agriculture. They rest primarily on mathematical modelling. Among them are spatial econometric models, which are concerned with spatial interactions (spatial autocorrelation) and spatial structures. Theoretical foundations of such models can be found in Paelinck and Klaassen (1979), Anselin and Florax (1995), or Griffith (2003). The application of spatial econometric models, or mathematical modelling, is a complex problem because it calls for an a priori judgement as to whether we deal with real-life or conceptual models. This does not preclude employing those models in research on the spatial structure of agriculture. But it makes it necessary, especially in the case of conceptual models, to assess their connection with objectively existing conditions and factors capable of being parameterised. Mathematical modelling methods offer much greater possibilities in the study of a spatial structure than the iconic, analogue and symbolic models employed in agricultural geography.

\section{Summing up}

The above overview of methods employed in the study of the spatial structure of agriculture gives one a good idea of the instruments researchers in this field have at their disposal today. However, the methods, whatever they are, only supply results which need an interpretation. An interpretation is the easier to work out the more data have been considered in the research. Each method requires parameterisation expressed in absolute or relative terms. The validity of assumptions is often decisive in making the results fit the reality examined. Therefore, despite the enormous progress in statistical and mathematical methods, traditional descriptive methods successfully employed so far to analyse and synthesise geographical phenomena will still remain in force.

Translated by Maria Kawińska

\section{References}

Anselin L., Florax R., 1995. New directions in spatial econometrics. Springer, Berlin.

Bański J., 2007. Geografia rolnictwa Polski (Agricultural geography of Poland). PWE, Warszawa.

Chojnicki Z., 1999. Podstawy metodologiczne i teoretyczne geografii (Methodological and theoretical foundations of geography). Bogucki Wydawnictwo Naukowe, Poznań.

Chojnicki Z., Czyż T., 1978. Podstawy metodologiczne zastosowania analizy czynnikowej (Methodological foundations of the application of factor analysis). In: Chojnicki Z., Czyż T., Parysek J., Ratajczak W. (eds), Badanie przestrzennej struktury spoteczno-ekonomicznej Polski metodami czynnikowymi. Geografia vol. 2. PWN, Poznań-Warszawa: 7-20.

Cramer G.L., Clarence W.J., 1994. Agricultural economics and agribusiness. Wiley, Sons, Inc., New York, Chichester, Brisbane, Toronto, Singapore.

Davies S., 1980. Measuring industrial concentration: An alternative approach. Review of Economics and Statistics 62(2): 306-309.

Falkowski J., Kostrowicki J., 2005. Geografia rolnictwa świata (Agricultural geography of the world). PWN, Warszawa.

Głębocki B., 1979. Czynniki kształtujące przestrzenna strukturę produkcyjna rolnictwa (Factors shaping the spatial production structure of agriculture). Wydawnictwo Naukowe UAM, Poznań.

Griffith D.A., 2003. Spatial autocorrelation and spatial filtering. Springer, Berlin.

Kołodziejczak A., 2002. Struktura upraw i produkcji ziemniaka $w$ Polsce w okresie przemian społeczno-gospodarczych w latach 1988-1993 (Structure of potato crops and production in Poland in the period of socio-economic changes over the years 1988-1993). Wydawnictwo PTPN, Poznań.

Kołodziejczak A., 2010. Modele rolnictwa a zróżnicowanie przestrzenne sposobów gospodarowania w rolnictwie polskim (Models of agriculture and spatial differences in farming patterns in Polish agriculture). Wydawnictwo Naukowe UAM, Poznań.

Kopeć B., 1984. Intensywność organizacji w rolnictwie polskim w latach 1960-1980 (Intensity of organisation in Polish agriculture in the years 1960-1980). Roczniki Nauk Rolniczych 84(1): 7-27.

Morrison D.F., 1967. Multivariate statistical methods. McGrawHill, New York.

Nowak E., 2004. Metody klasyfikacji w badaniach geograficznych (analiza porównawcza) (Classification methods in geographical research: a comparative analysis). Bogucki Wydawnictwo Naukowe, Poznań.

Paelinck J.H.P., Klaassen L.H., 1983. Spatial econometrics. Saxon House, Farnborough.

Parysek J., 1980. Analiza skupień jako metoda kwalifikacji w geografii (Cluster analysis as a qualification method in geography). In: Chojnicki Z. (ed.), Metody taksonomiczne w geografii. PWN, Poznań-Warszawa: 87-99.

Parysek J., Ratajczak W., 1978. Analiza głównych składowych cech charakteryzujących właściwości społecznoekonomiczne i środowisko geograficzne Polski w 1970 r. (Principal components analysis of variables characterising Poland's socio-economic properties and geographical environment in 1970). In: Chojnicki Z., Czyż T., Parysek J., Ratajczak W. (eds), Badanie przestrzennej struk- 
tury spoteczno-ekonomicznej Polski metodami czynnikowymi. PWN, Poznań-Warszawa: 83-106.

Parysek J., Ratajczak W., 2002. Analiza składowych głównych, jej korzyści i ograniczenia zastosowań metod badawczych z punktu widzenia badań geograficznych (Principal components analysis, its advantages and limitations in the application of research methods: A geographical research perspective). In: Rogacki H. (ed.), Możliwości i ograniczenia zastosowań metod badawczych w geografii społeczno-ekonomicznej i gospodarce przestrzennej. Bogucki Wydawnictwo Naukowe, Poznań: 61-74.

Runge J., 2006. Metody badań w geografii społeczno-ekonomicznej - elementy metodologii, wybrane narzędzia badawcze (Research methods in socio-economic geography: elements of methodology and selected research instruments). Wydawnictwo Uniwersytetu Sląskiego, Katowice.

Weaver J.C., 1956. Livestock units and combination regions in the Middle West. Economic Geography 32(3): 237-244. 